\title{
Meloidogyne incognita and Meloidogyne javanica (Rhabditida: Meloidogynidae): first report parasitizing cassava in Goiás State, Brazil
}

\author{
J. O. Oliveira ${ }^{a}$ (D) R. V. Silva ${ }^{a}$, J. P. E. Gondimª (i) J. P. M. Furtado ${ }^{a}$, B. M. C. Castro ${ }^{\text {* }}$ (D) and J. C. Zanuncio ${ }^{\text {(D) }}$ \\ anstituto Federal Goiano, Laboratório de Nematologia Agrícola, Programa de Pós-graduação em Olericultura, Campus Morrinhos, \\ Morrinhos, GO, Brasil \\ 'Universidade Federal de Viçosa - UFV, Departamento de Entomologia/BIOAGRO, Viçosa, MG, Brasil
}

Cassava (Manihot esculenta Crantz), an important subsistence culture in developing countries (Oliveira et al., 2020), is the third main source of carbohydrates (Ramcharan et al., 2017) for approximately 800 million people worldwide (Rocha et al., 2020). This plant is easily propagated by stem segment (Atwijukire et al., 2019) with good resistance to water stress conditions and high temperatures (Gabriel et al., 2014) and demanding few cultural treatments. In addition, its harvest occurs throughout the year, which increases its importance for small producers in the arid climate regions of Brazil (Aparecido et al., 2020).

Associations of phytoparasitic nematodes and cassava plants are poorly known in Brazil, despite the socioeconomic importance of this plant (Rosa et al., 2014). The nematodes Meloidogyne incognita, Pratylenchus brachyurus, Rotylenchulus reniformis and Scutellonema bradys parasitized cassava roots and Aphelenchoides sp., Aphelenchus sp., Helicotylenchus sp., Mesocriconema sp. and Tylenchus sp. were obtained in the rhizosphere of this plant (Garrido et al., 2008).

Meloidogyne spp. induce gall formation in plant roots, disrupting the cortex and the vascular cylinder and reducing the absorption and transport of water and nutrients. This causes yellowing, wilting and reduced growth (Williamson and Gleason, 2003; Anwar and Javed, 2010; Khan et al., 2020), besides increasing the susceptibility of infected plants to bacteria, fungi and phytopathogenic viruses (Al-Hazmi and Al-Nadary, 2015; Ali et al., 2017).

Meloidogyne incognita and Meloidogyne javanica, the most harmful nematode species to Brazilian agriculture (Mazzonetto et al., 2015), are aggressive with high reproduction rate (Hemmati and Saeedizadeh, 2020) and wide dissemination and geographical distribution (Garrido et al., 2008). Meloidogyne incognita parasitized cassava plants in the Brazilian Amazon (Rosa et al., 2014), but M. javanica was not reported on this plant in this country. The objective of this work is to report the occurrence of the nematodes M. incognita and M.javanica parasitizing cassava plants in agricultural soils in the state of Goiás in the center-western region of Brazil.

Cassava-producing areas registered by the "Empresa de Assistência Técnica e Extensão Rural do Estado de Goiás (EMATER/GO)" in the municipalities of Morrinhos (17 $45^{\prime}$

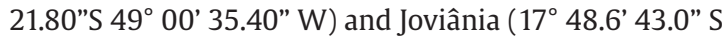
$49^{\circ} 36.7^{\prime} 25.0^{\prime \prime}$ ) were studied. Samples with $500 \mathrm{~g}$ of soil and $100 \mathrm{~g}$ of roots each composed of fifteen sub-samples collected near the rhizosphere at a depth of $20-25 \mathrm{~cm}$ were packed in plastic bags inside Styrofoam boxes identified and stored in a refrigerator for a maximum of eight days $\left(8{ }^{\circ} \mathrm{C}\right)$ before being analyzed.

Cassava roots, without visible symptoms of galls or nematode females, in good condition for biochemical analysis, were placed in polyethylene pots $(1 \mathrm{~L})$ with a tomato host plant Solanum lycopersicum, cv. Santa Cruz grown in a mixture of soil and sand in a proportion of $2: 1(\mathrm{v} / \mathrm{v})$ previously autoclaved $\left(120^{\circ} \mathrm{C}\right.$ for $2 \mathrm{~h}$ ) to multiply the possible Meloidogyne species present. After 60 days of cultivation in a greenhouse, the tomato roots were sent for biochemical analysis.

Meloidogyne spp. eggs were extracted from tomato roots with galls, but without females of these pathogens, for biochemical analysis (adult females and milky whitish females), by the domestic blender method (Boneti and Ferraz, 1981). The roots of the tomato were washed in running water, chopped into $1-2 \mathrm{~cm}$ pieces and crushed in a blender with $0.5 \% \mathrm{NaOCl}$ solution for 20 seconds. The obtained egg suspension was immediately poured through a 200 mesh $(0.074 \mathrm{~mm})$ sieve coupled to a 500 mesh $(0.025 \mathrm{~mm})$ sieve. These eggs were quantified in a Peters counting chamber and the suspension calibrated to $1000 \mathrm{~mL}^{-1}$ eggs under a photonic microscope (100X magnification). Tomato plants cv. Santa Cruz Kada were inoculated with 5,000 eggs of the nematode per polyethylene pot of $1 \mathrm{~L}$ capacity containing a mixture of soil and sand, previously autoclaved in the proportion of $2: 1(\mathrm{v} / \mathrm{v})$. The gall nematodes were multiplied in a greenhouse at a temperature of $25+/-2{ }^{\circ} \mathrm{C}$ for 60 days and sent for biochemical analysis. 
The root samples with galls, containing some soil to maintain the moisture, were packed in plastic bags and sent for analysis to the Laboratório de Nematologia of the Universidade Federal de Viçosa (UFV). Meloidogyne spp. species were identified by biochemical analysis of its females and isoenzyme esterase electrophoresis (EST) by the vertical discontinuous system (mini-Protean 3/ Bio-Rad) (Freitas et al., 2016).

The gall nematodes in the samples collected from cassava roots were identified as M. incognita and M.javanica by the esterase phenotypes I1 and J3, respectively (Figure 1). Infected plants were underdeveloped with symptoms of nitrogen deficiency, few secondary roots and galls ranging from $0.5 \mathrm{~mm}$ to $3 \mathrm{~cm}$ in diameter, in addition to cracking and root stripping (Figure 2 ) and nematodes signals were observed in samples (Figure 3 ).

The identification of $M$. incognita in the state of Goiás increases the area of occurrence of this nematode in cassava plants after its report in the states of Amapá and Pará, Brazil (Rosa et al., 2014). Infection with Meloidogyne spp. reduced the fresh matter mass of the plant crown, plant height, fresh mass and number of roots in susceptible cassava cultivars in Uganda and Nigeria (Coyne and Talwana, 2000; Akinsanya and Afolami, 2019). In addition, it reduced
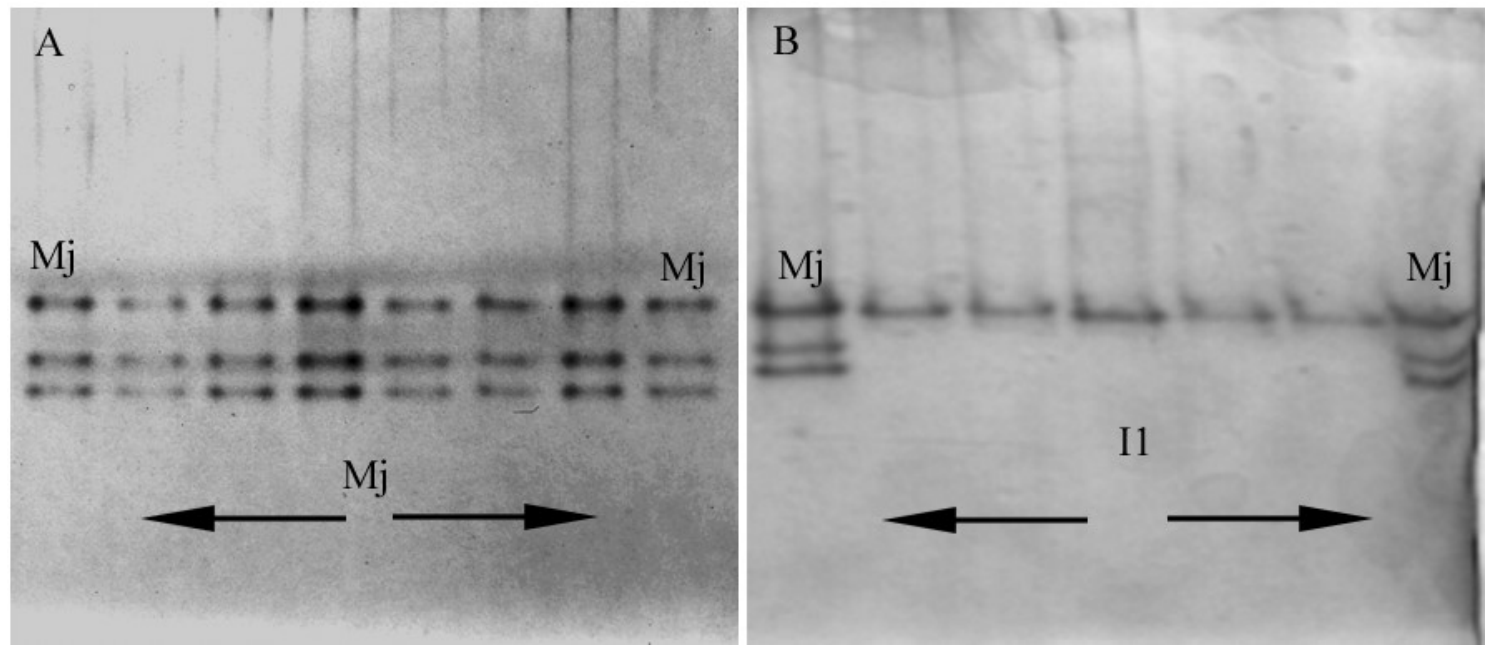

Figure 1. Root-knot nematode extracted from cassava roots (Manihot esculenta). Isoenzymatic phenotypes of female esterase: Mj (Rm: 1.0; 1.25 and 1.4) from Meloidogyne javanica (A) and I1 ( $\mathrm{Rm}=1.0)$ from Meloidogyne incognita. Mj phenotype of M. javanica used as a standard (B).
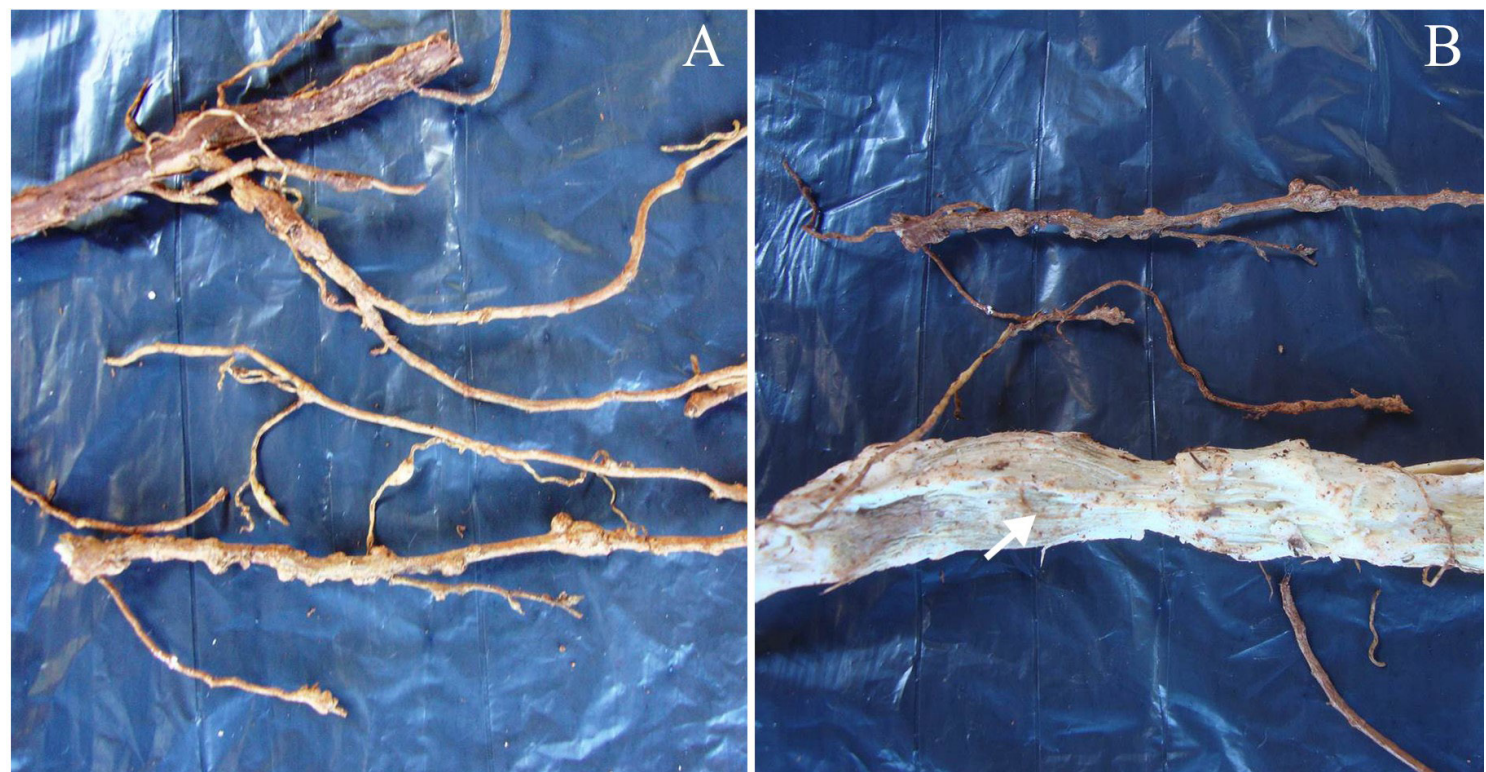

Figure 2. Meloidogyne incognita galls in roots of cassava plants (Manihot esculenta) (A, B); stripped roots (indicated by arrow) (B). 

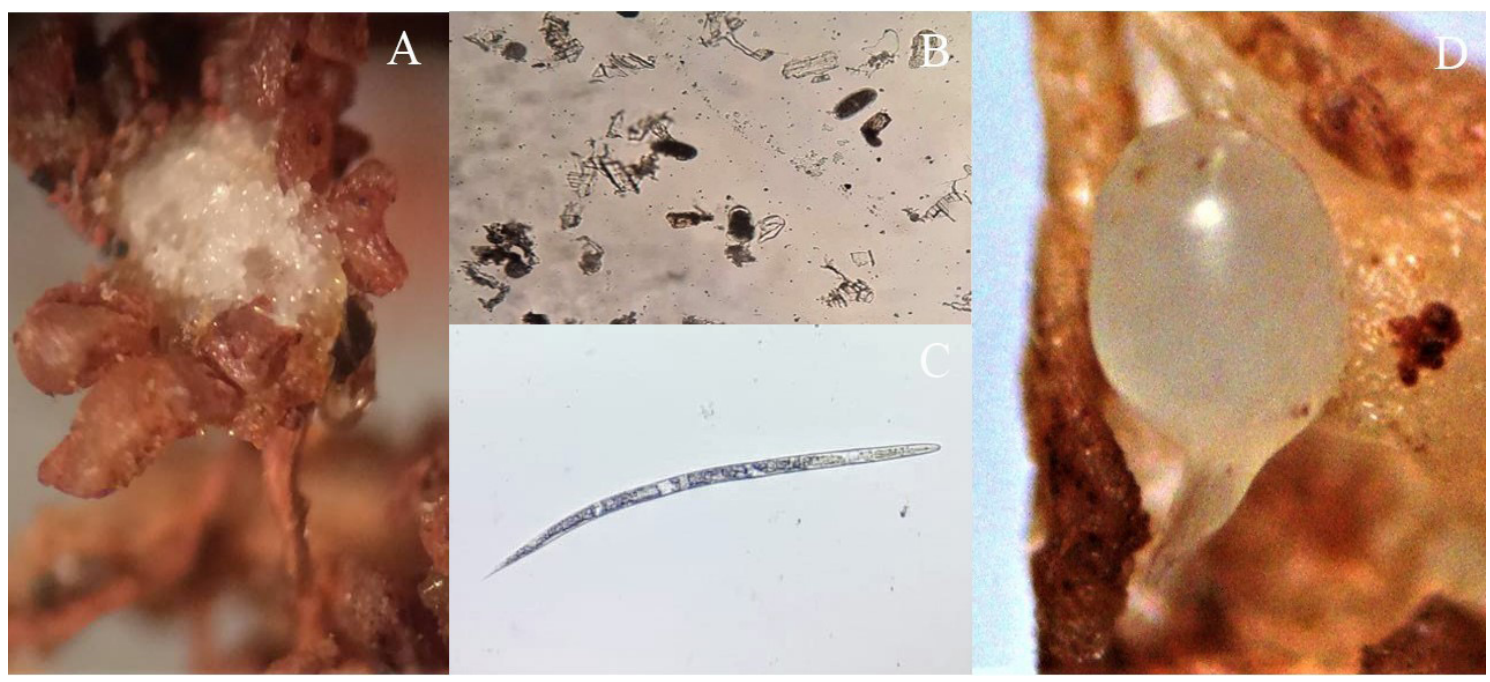

Figure 3. Meloidogyne incognita galls in roots of cassava plants (Manihot esculenta): Egg mass (A); eggs (B), juveniles 2nd stage (C) and exposed female at the root (D).

the sprouting and the establishment of cassava cuttings (Talwana et al., 1997; Makumbi-Kidza et al., 2000). Damage by Meloidogyne spp. reduced the productivity of cassava in the field in Nigeria (Abidemi, 2014) and increased the incidence of rot on roots of this plant stored (Akinsanya and Afolami, 2018; Coyne and Affokpon, 2018). The reduction in cassava productivity by M. incognita is due to the decrease in the number of reserve roots of this plant (MakumbiKidza et al., 2000). Nematode management is difficult, but preventive tactics, including the use of phytoparasitic nematode-free equipment, healthy propagating material and crop rotation, can reduce the damage by these pathogens (Akinsanya et al., 2020).

The diagnosis of M. incognita and M. javanica in cassava represents the first report of these species parasitizing this plant in Brazil.

\section{Acknowledgements}

To, Ph.D. Rosangela D 'Arc de Lima Oliveira, Dalila Seni Jesus and Aline Barros Ferreira for technical support. To Fundação de Amparo a Pesquisa de Goiás (FAPEG) pela concessão da bolsa de estudos. To "Instituto Federal de Educação, Ciência e Tecnologia Goiano (IFGoiano)", "Conselho Nacional de Desenvolvimento Científico e Tecnológico (CNPq)", "Coordenação de Aperfeiçoamento de Pessoal de Nível Superior (CAPES - Finance Code 001), "Fundação de Amparo à Pesquisa do Estado de Minas Gerais (FAPEMIG)" and "Programa Cooperativo sobre Proteção Florestal (PROTEF) do Instituto de Pesquisas e Estudos Florestais (IPEF)" for financial support.

\section{References}

ABIDEMI, M.O., 2014. Plant-parasitic nematodes associated with cassava in southwestern Nigeria and control of Meloidogyne incognita with Tithonia diversifolia and plastic mulch.Ibadan: University of Ibadan, pp. 185-200. Ph.D. Thesis in Plant Pathology.

AKINSANYA, A.K. and AFOLAMI, S.O., 2018. Effect of seven elite cassava (Manihot esculenta Crantz) varieties to infection by Meloidogyne spp. and other nematodes in the field.Nematropica, vol. 48 , no. 1, pp. 50-58.

AKINSANYA, A.K. and AFOLAMI, S.O., 2019. Screen house response of seven elite cassava (Manihot esculenta Crantz) varieties to Meloidogyne incognita infection.Nematropica, vol. 49, no. 1, pp. 91-98.

AKINSANYA, A.K., AFOLAMI, S.O., KULAKOW, P. and COYNE, D., 2020. The root-knot nematode, Meloidogyne incognita, profoundly affects the production of popular biofortified cassava cultivars.Nematology, vol. 22, no. 6, pp. 667-676. http://dx.doi. org/10.1163/15685411-00003331.

AL-HAZMI, A.S. and AL-NADARY, S.N., 2015. Interaction between Meloidogyne incognita and Rhizoctonia solani on green beans. Saudi Journal of Biological Sciences, vol. 22, no. 5, pp. 570-574. http://dx.doi.org/10.1016/j.sjbs.2015.04.008. PMid:26288560.

ALI, N., TAVOILLOT, J., BESNARD, G., KHADARI, B., DMOWSKA, E., WINISZEWSKA, G., FOSSATI-GASCHIGNARD, O., ATER, M., AÏT HAMZA, M., EL MOUSADIK, A., EL OUALKADI, A., MOUKHLI, A., ESSALOUH, L., EL BAKKALI, A., CHAPUIS, E. and MATEILLE, T., 2017. How anthropogenic changes may affect soil-borne parasite diversity? Plant-parasitic nematode communities associated with olive trees in Morocco as a case study.BMC Ecology, vol. 17, no. 1, pp. 4. http://dx.doi.org/10.1186/s12898-016-0113-9. PMid:28166763.

ANWAR, S.A. and JAVED, N., 2010. Meloidogyne incognita infecting Dahlia.Pakistan Journal of Zoology, vol. 42, no. 3, pp. 348-350.

APARECIDO, L.E.O., ROLIM, G.S., MORAES, J.R.S.C., COSTA, C.T.S. and OLIVEIRA, P.S., 2020. Machine learning algorithms for forecasting the incidence of Coffea arabica pests and diseases.International Journal of Biometeorology, vol. 64, no. 4, pp. 671-688. http:// dx.doi.org/10.1007/s00484-019-01856-1. PMid:31912306.

ATWIJUKIRE, E., HAWUMBA, J.F., BAGUMA, Y., WEMBABAZI, E., ESUMA, W., KAWUKI, R.S. and NUWAMANYA, E., 2019. Starch quality traits of improved provitamin A cassava (Manihot esculenta Crantz).Heliyon, vol. 5, no. 2, pp. e01215. http://dx.doi. org/10.1016/j.heliyon.2019.e01215. 
BONETI, J.I.S. and FERRAZ, S., 1981. Modificação do método de Hussey \& Barker para extração de ovos de Meloidogyne exigua de raízes de cafeeiro.Fitopatologia Brasileira, vol. 6, pp. 553.

COYNE, D.L. and AFFOKPON, A.2018. Nematode parasites of tropical root and tuber crops. In: R.A.SIKORA, D.L.COYNE, J.HALLMAN and P.TIMPER, eds. Plant parasitic nematodes in subtropical and tropical agriculture.3rd ed. Wallingford: CAB International, pp. 252-289. http://dx.doi.org/10.1079/9781786391247.0252.

COYNE, D.L. and TALWANA, L.A.H., 2000. Reaction of cassava cultivars to root-knot nematode (Meloidogyne spp.) in pot experiments and farmer-managed field trials in Uganda.International Journal of Nematology, vol. 10, pp. 153-158.

FREITAS, L.G., NEVES, W.S., OLIVEIRA, R. and D'ARC, L., 2016. Métodos em nematologia vegetal. In: A.C.ALFENAS and R.G.MAFIA, eds. Métodos em fitopatologia. $2^{\underline{a}}$ ed. Viçosa: Editora UFV, pp. 257-296.

GABRIEL, L.F., STRECK, N.A., UHLMANN, L.O., MICHEL, R., DA SILVA, M.R. and SILVA, S.D., 2014. Climate change and its effects on cassava crop.Revista Brasileira de Engenharia Agrícola e Ambiental, vol. 18, no. 1, pp. 90-98. http://dx.doi.org/10.1590/ S1415-43662014000100012.

GARRIDO, M.S., COIMBRA, J.L., SOARES, A.C.F., ALMEIDA, N.S. and SOUSA, C.S., 2008. Fitonematoides associados à rizosfera e raízes da mandioca cultivada em rotação com inhame cultivar da Costa.Summa Phytopathologica, vol. 34, no. 2, pp. 181-182. http://dx.doi.org/10.1590/S0100-54052008000200015.

HEMMATI, S. and SAEEDIZADEH, A., 2020. Root-knot nematode, Meloidogyne javanica, in response to soil fertilization.Brazilian Journal of Biology $=$ Revista Brasileira de Biologia, vol. 80, no. 3, pp. 621-630. http://dx.doi.org/10.1590/1519-6984.218195. PMid:31644656.

KHAN, R., NAZ, I., HUSSAIN, S., KHAN, R.A.A., ULLAH, S., RASHID, M.U. and SIDDIQUE, I., 2020. Phytochemical management of root knot nematode (Meloidogyne incognita) kofoid and white chitwood by Artemisia spp.in tomato (Lycopersicon esculentum L.).Brazilian Journal of Biology = Revista Brasileira de Biologia, vol. 80, no. 4, pp. 829-838. http://dx.doi.org/10.1590/15196984.222040. PMid:31800766.
MAKUMBI-KIDZA, N.N., SPEIJER, P.R. and SIKORA, R.A., 2000. Effects of Meloidogyne incognita on growth and storage-root formation of cassava (Manihot esculenta).Journal of Nematology, vol. 32, no. 4S, pp. 475-477. PMid:19270997.

MAZZONETTO, F., SOSSAI, V.L.M., BENASSATTO, R., MELO, V.P. and PIZETTA, L.C., 2015. Avaliação da eficiência do extrato aquoso de mandioca sobre Meloidogyne incognita in vitro.Revista Agrogeoambiental, vol. 7, no. 4, pp. 105-112.

OLIVEIRA, E.J., OLIVEIRA, S.A.S., OTTO, C., ALICAI, T., DE FREITAS, J.P.X., CORTES, D.F.M., PARIYO, A., LIRI, C., ADIGA, G., BALMER, A., KLAUSER, D. and ROBINSON, M., 2020. A novel seed treatmentbased multiplication approach for cassava planting material. PLoS One, vol. 15, no. 3, e0229943. http://dx.doi.org/10.1371/ journal.pone.0229943.

RAMCHARAN, A., BARANOWSKI, K., MCCLOSKEY, P., AHMED, B., LEGG, J. and HUGHES, D.P., 2017. Deep learning for imagebased cassava disease detection.Frontiers in Plant Science, vol. 8, pp. 1852. http://dx.doi.org/10.3389/fpls.2017.01852. PMid:29163582.

ROCHA, V.P.C., GONÇALVES-VIDIGAL, M.C., ORTIZ, A.H.T., VALENTINI, G., FERREIRA, R.C.U., GONÇALVES, T.M., LACANALLO, G.F. and VIDIGAL FILHO, P.S., 2020. Population structure and genetic diversity in sweet cassava accessions in Paraná and Santa Catarina, Brazil.Plant Molecular Biology Reporter, vol. 38, no. 1, pp. 25-38. http://dx.doi.org/10.1007/s11105-019-01175-0.

ROSA, J.M.O., OLIVEIRA, S.A., JORDÃO, A.L., SIVIERO, A. and OLIVEIRA, C.M.G., 2014. Nematoides fitoparasitas associados à mandioca na Amazônia brasileira.Acta Amazonica, vol. 44, no. 2, pp. 271275. http://dx.doi.org/10.1590/S0044-59672014000200013.

TALWANA, H.A.L., SPEIJER, P.R., ADIPALA, E. and MALSEN, N.R.,1997. The effect of preplant population densities of root-knot nematodes on the establishment of cassava cuttings.In:E. ADIPALA, J.S.TENYWA and M.W.OGENGA-LATIGO,eds. All-African Crop Science Congress Proceedings.Pretoria: African Crop Science Society, vol. 3, pp. 1239-1242.

WILLIAMSON, V.M. and GLEASON, C.A., 2003. Plant-nematode interactions.Current Opinion in Plant Biology, vol. 6, no. 4, pp. 327-333. http://dx.doi.org/10.1016/S1369-5266(03)00059-1. PMid:12873526. 